\title{
O ENSINO DE LÍNGUA INGLESA SOB UMA PERSPECTIVA INTERCULTURAL: CAMINHOS E DESAFIOS
}

\section{ENGLISH LANGUAGE TEACHING FROM AN INTERCULTURAL PERSPECTIVE: PATHWAYS AND CHALLENGES}

\section{Flavia Matias da Silva*}

\section{RESUMO}

Este artigo busca discutir a importância do ensino intercultural (BYRAM, 2008; SIQUEIRA, 2008, 2011, 2013; KRAMSCH, 2001) de língua inglesa na Educação Básica a partir da análise das respostas de alunos do segundo ano do Ensino Médio Regular do Colégio Estadual Pandiá Calógeras, que fica localizado do município de São Gonçalo - RJ. No segundo semestre do ano letivo de 2017, esses alunos tiveram contato, por meio de um exercício de compreensão oral elaborado pela professora regente, com variedades que representam dois modelos distintos de inglês, a saber, o hegemônico, representado por um falante norteamericano, e o não hegemônico, representado por um falante indiano. Durante a atividade, grande parte dos alunos pesquisados apresentou predileção pelo sotaque norte-americano e, por sua vez, preteriram o indiano, corroborando, assim, a importância da implementação de atividades que promovam um olhar crítico acerca da língua inglesa no contexto escolar. Diante disto, devemos salientar que o ensino de língua inglesa apresentado neste estudo é norteado pelas premissas do inglês como língua franca (ILF), cuja definição ressignificada não se encaixa ao seu conceito antigo. (SIQUEIRA \& BARROS, 2013)

Palavras-chave: interculturalidade; inglês como língua franca; ensino e aprendizagem de língua estrangeira.

\section{ABSTRACT}

This article aims to discuss the importance of intercultural language teaching (BYRAM, 2008; SIQUEIRA, 2008, 2013; KRAMSCH, 2001) in school education based on analysis of the responses of sophomore students from Pandiá Calógeras State School, which is located in the municipality of São Gonçalo - RJ. In the second semester of 2017, through a listening exercise designed by the teacher, these students had contact with varieties that represent two distinct types of English, that is, the hegemonic model, which was represented by a North American speaker, and the non-hegemonic one which was represented by an Indian speaker. During the activity, a large proportion of the students preferred the North American accent and disregarded the Indian one. Thus, this scenario corroborates the importance of intercultural activities that promote critical reflection on the English language within the school context. It is also important to point out that the English language teaching perspectives presented in this study are guided by the premises of English as a lingua franca

\footnotetext{
* Universidade Federal Fluminense (UFF), Niterói, RJ, Brasil. flaviamatias@id.uff.br
} 
(ILF), whose re-signified definition has moved beyond the original concept. (SIQUEIRA \& BARROS, 2013)

Keywords: interculturality ${ }_{i}$ English as a lingua franca; teaching and learning of a foreign language.

\section{INTRODUÇÃO}

O ensino de uma língua estrangeira (LE) pelo viés intercultural transcende o ensino de estruturas linguísticas e adentra o universo das estruturas sociais nas quais se funda a própria língua. Além disso, por meio dos aspectos culturais, o aprendiz pode compreender as escolhas estruturais de outros sistemas linguísticos para dar conta do mesmo significado, sem que haja julgamento de valor, uma vez que a descoberta de inúmeras possibilidades de dizer enriquece os falantes e os torna mais aptos a participar do desafiador jogo social permeado pela linguagem. (FERNANDES; EIRÓ, 2013, p. 108) Nesse sentido, o ensino de língua estrangeira sob uma perspectiva intercultural apresenta uma ótica que valoriza as diferentes experiências e vivências dos alunos, viabilizando, assim, por meio, da interação com outros saberes, a co-construção do aprendizado.

No entanto, de acordo com Kramsch (2013, p. 58-59), ainda há muitos contextos educacionais em que o ensino de língua enfoca de forma dissociada $\mathrm{da}(\mathrm{s})$ cultura(s) a competência comunicativa e as habilidades linguísticas voltadas, principalmente, à produção oral. Nesse contexto, é comum também a valorização de professores que sejam falantes nativos, pois, para muitas escolas, eles apresentam maior legitimidade para ensinar a língua. Contudo, para Kirkpatrick (2007 apud SIQUEIRA, 2011b, p. 348), deve-se ressaltar que por conta da explosão de falantes não-nativos de língua inglesa ao redor do mundo, os modelos nativizados tidos como referência de uso não apresentam mais a garantia de serem os mais internacionalmente inteligíveis. Além disso, outro dado interessante é que $80 \%$ dos profissionais da área de ensino de inglês ao redor do mundo não são nativos (CANAGARAJAH, 1999 apud SOUZA; BARCARO et al, 2011, p. 207). Diante desse cenário, sustentar a predileção por modelos hegemônicos da língua inglesa no contexto educacional, especialmente em contextos como o Brasil, não representa a realidade vivida pelos aprendizes.

Sendo assim, este artigo objetiva discutir a importância do ensino intercultural de língua inglesa na Educação Básica a partir da análise das respostas de alunos de duas turmas de $2^{\circ}$ ano do Ensino Médio Regular noturno do Colégio Estadual Pandiá Calógeras, que fica localizado no município de São Gonçalo - RJ. Grosso modo, no segundo semestre do ano de 2017, os alunos realizaram um exercício de 
compreensão oral em que tiveram contato com variedades que representam dois tipos distintos de inglês, a saber, o tido como hegemônico, representado por um falante norte-americano, e o não hegemônico, representado por um falante indiano.

Foi interessante observar, que durante a atividade, grande parte dos alunos pesquisados apresentou predileção pelo sotaque norte-americano, classificando-o como belo e original. Tais asserções corroboram a importância da implementação de atividades de viés intercultural, que promovam um olhar mais crítico e menos colonizado acerca do ensino e aprendizagem de língua inglesa.

Portanto, cabe também destacar que a definição de inglês apresentada neste estudo alinha-se ao conceito focalizado por Siqueira \& Barros (2013, p. 9), não se encaixando, desse modo, no conceito antigo de língua franca, em que se concebe uma língua neutra, esvaziada de cultura, cujo objetivo utilitário opera numa "zona franca", "terra de ninguém", sem vínculo com os aspectos ideológicos e culturais trazidos pelos falantes durante a interação.

\section{A IMPORTÂNCIA DA EDUCAÇÃO INTERCULTURAL NA EDUCAÇÃO BÁSICA}

O papel que a língua inglesa vem adquirindo em nível mundial nos tempos de globalização em que vivemos comprova o seu destaque em relação aos outros idiomas:

A língua se tornou uma espécie de 'língua mundi' ou a que prefiro chamar de 'World English' (cf. Rajagopalan, 2004, 2005, 2006) é uma 'novi-língua' em plena acepção desse termo popularizado por George Orwell. Ela já escapou das mãos dos ingleses, dos norte-americanos, dos australianos, dos novo-zelandeses, enfim de todos aqueles que até bem pouco tempo atrás eram tidos como proprietários do idioma. (RAJAGOPALAN, 2014, p, 76)

Para Siqueira (2011a, p. 90), ensinar essa língua híbrida e franca, que é o inglês, demanda uma visita diária a novas fronteiras, que, por sua vez, geram novas prioridades, dentre as quais as pedagogias mais adequadas para tal realidade. Portanto, estabelece-se como desafio a implementação de práticas pedagógicas que ressignifiquem o ensino de língua inglesa, tendo, por conseguinte, como enfoque o seu caráter híbrido e multifacetado.

É importante também salientar que o ensino de língua inglesa à luz das premissas do inglês como língua franca (ILF) não objetiva rechaçar a importância do inglês comumente tido como hegemônico, nem, muito menos, estabelecer ou enfatizar a dicotomia entre língua padrão e não padrão. Na verdade, essa dicotomia corroboraria ainda mais a hegemonia da língua padrão (SILVERSTEIN 1996, p. 284 apud MILROY, 2011, p. 63). 
No que tange ao ensino de língua inglesa, o que de fato precisa prevalecer no contexto escolar brasileiro é a busca pela maior viabilização de práticas pedagógicas que também promovam o caráter heterogêneo da língua, visto que um efeito importante da padronização para o senso comum é o desenvolvimento da crença em uma única forma de língua correta. Tal ideologia gera juízos carregados de preconceitos e de descriminação em termos de raça e classe social. (MILROY, 2011, p. 57-59)

Nessa direção, Gimenez, Calvo \& El Kadri (2011, p. 15-16) destacam que os motivos para se aprender inglês precisam enfatizar a ideia de que a comunicação com outros falantes não-nativos de inglês ao redor do mundo é relevante. Além disso, outras variedades da língua inglesa que não apenas norte-americana ou britânica precisam ser apresentadas aos alunos no desenvolvimento das habilidades receptivas e nas de compreensão, assim como os temas trazidos para a sala de aula, os quais abrangem questões sociais de alcance global, precisam ser ampliados. Além disso, faz-se necessária uma maior conscientização sobre o papel das línguas nas sociedades e, especialmente, do inglês como língua de comunicação internacional, bem como sobre sua expansão no mundo e sua vinculação com a [atual] globalização econômica.

Como bem sublinha Siqueira (2011a, p. 109), ensinar e aprender inglês como língua franca implica colorir as salas de aula com diversos sotaques oriundos de lugares distantes e esquecidos, trazendo as vozes dos guetos, das minorias, dos imigrantes com suas tradições culturais de diferentes continentes, como a África, Ásia e América, e até do interior das grandes metrópoles dos países hegemônicos de língua inglesa.

\section{A HETEROGENEIDADE DA LÍNGUA INGLESA: QUESTÕES TERMINOLÓGICAS}

O caráter heterogêneo da língua inglesa hoje pode ser também notado nos inúmeros termos e conceitos que emergem objetivando defini-lo. Por exemplo, Kachru (1985) optou pelo conceito de World Englishes (ingleses mundiais), para definir, em princípio, variantes nativizadas e emergentes da língua inglesa no mundo, em especial, aquelas que se desenvolveram a partir do processo de colonização britânico. O termo também refere-se às variações formais e funcionais, contemplando os diferentes contextos sociolinguísticos, e aos vários tipos de aculturação ao redor do mundo. 
Além disso, o conceito de World Englishes apresentado por Kachru (1985) focaliza a ideia de "WE-ness" ${ }^{1}$, rejeitando o estabelecimento de dicotomias entre falantes nativos e não-nativos, imprimindo, dessa forma, a ideia de aproximação e comunhão entre os falantes da língua inglesa.

No que diz respeito à difusão do inglês no mundo, a proposta apresentada por Kachru (1985) acerca da organização da língua inglesa sofreu diversas críticas. Na tentativa de classificar tanto em status quanto em números aproximados os grupos de falantes da língua inglesa, Kachru (1985) apresentou o processo de expansão a partir de três círculos, a saber, círculos central, externo e em expansão.

O círculo central, ou Inner circle, abrange as áreas onde o inglês é a língua materna da população. Neste grupo estão os Estados Unidos, Irlanda, Canadá, Austrália, Nova Zelândia e Reino Unido. O círculo externo, ou Outer Circle, seria representado por países em que o inglês opera como segunda língua em comunidades multilíngües e multiculturais como Cingapura, Nigéria, Índia e Filipinas. Por fim, o círculo em expansão, ou Expanding circle, refere-se aos países que reconhecem o inglês como língua internacional a despeito de não possuírem uma história de colonização por parte de países do circulo central, e de também não utilizarem a língua inglesa como idioma oficial em suas instituições. Neste círculo, o inglês é geralmente estudado como língua estrangeira e dele fazem parte países como Portugal, China, Brasil, Egito, Grécia, e muitos outros. (SIQUEIRA, 2011b, p. 337)

As críticas aos círculos concêntricos devem-se ao fato de ele homogeneizar os diferentes ingleses em círculos distintos, ignorando o caráter híbrido da língua inglesa. Por exemplo, Rajagopalan (2005 apud SIQUEIRA, 2011b, p. 338), apesar de reconhecer a importância dessa tipologia, assinala que a figura dos três círculos concêntricos

[...] lembra uma fruta em corte, onde os países do círculo central ocupam a posição de semente, isto é, de fonte original, de onde partem os modelos e as políticas que perpassam pela camada interna, o miolo, onde se localizam os países do círculo externo, até alcançarem a última camada, a casca, representada pelos países do círculo em expansão. (RAJAGOPALAN, 2005 apud SIQUEIRA, 2011b, p. 338, grifo do autor)

Outra visão sobre a heterogeneidade do inglês contemporâneo é a de Crystal (2003, p. 144). O autor denomina as diferentes variedades da língua inglesa no mundo atual de new Englishes. Além disso, compara esses "novos ingleses" aos dialetos existentes em qualquer país falante de língua inglesa como L1, sendo sua

1. We é o pronome pessoal "nós" em língua portuguesa e -ness é um sufixo que determina a formação de muitos substantivos em língua inglesa. Além disso, WE é acrônimo de World Englishes. 
especificidade o fato de que se encontram em uma escala internacional, pertencendo a diversos países ou regiões. ${ }^{2}$

Já para Pennycook (2010), as variedades da língua inglesa sempre existiram localmente. Por analogia com o hip-hop ${ }^{3}$, o referido autor assinala que o inglês hoje tido como global e híbrido, na verdade, não teria suas origens na expansão da língua inglesa pelo mundo. Ele seria, de fato, o resultado de interações linguísticas locais. Ainda segundo ele, as narrativas de expansão, transição, desenvolvimento e origem precisam ser repensadas em termos de multiplicidade, heterogeneidade e simultaneidade. Tal concepção acerca dos ingleses globais redefine o entendimento sobre a cultura global e local e sobre as formações linguísticas, indo além da discussão sobre os modelos monocêntricos e pluricêntricos da língua inglesa.

Dentre essas inúmeras terminologias, encontramos também o inglês como língua internacional (ILI) e o inglês como língua franca (ILF). O ILF faz parte de um paradigma de inglês global, pois grande parte de seus falantes não são nativos; contudo, todas as variedades da língua são aceitas ao invés de serem preteridas em relação às variedades concebidas como hegemônicas e padrão. Decerto, nenhuma definição para ILF pode ser completa caso não sejam consideradas questões relativas à expansão do inglês pelo mundo e à maneira que os novos ingleses expressam a identidade sociocultural de seus falantes (JENKINS; COGO; DEWEY, 2011, p. 283-28).

Já o ILI, pode ser concebido como "um termo guarda-chuva que caracteriza os usos do inglês entre dois falantes quaisquer de inglês como segunda língua oriundos ou não da mesma cultura, assim como falantes de inglês como segunda língua ou língua nativa" (McKAY; BOKHORST-HENG, 2008, p. 16 apud SIQUEIRA, 2011a, p. 94).

Sendo assim, optaremos em conceber ambos os paradigmas como

(...) correntes tributárias que terminam por confluírem para o mesmo destino. Em outras palavras, semelhante ao ILI, a definição "mais ampla" de ILF reconhece o seu caráter pluricêntrico, acolhe falantes do círculo central e externo na comunicação intercultural, não se rendendo, contudo, à imposição de suas normas nem muito menos à sua carga cultural, já que a ideia não é codificar uma variedade de ILF única, monolítica (algo certamente impossível em se tratando de língua) ou seguir um modelo baseado no falante nativo. (SIQUEIRA, 2011a, p. 96)

2. Citação na versão original: "These new Englishes are somewhat like the dialects we recognize within our own country, except that they are on an international scale, applying to whole countries or regions." (CRYSTAL, 2003, p. 144)

3. A alusão feita ao hip-hop é devido ao fato de essa expressão cultural ter facetas múltiplas, porém, sua origem ter sempre sido local, assim como uma cultura aborígene. 
Por fim, diante das diferentes óticas sobre a presença da língua inglesa no mundo, é também interessante refletir sobre o ensino de língua inglesa (ELI) no contexto educacional brasileiro com base nas asserções de Faraco (2007, p. 42) acerca do ensino da língua portuguesa. Para o autor supracitado, estamos muito atrasados na construção de uma pedagogia de variação linguística, uma vez que a escola ainda não está apta a lidar com a diversidade linguística de forma adequada.

Assim, faz-se necessário o desenvolvimento de uma pedagogia que vise a desenvolver práticas que saibam transitar pelas diversas nuances da língua inglesa, superando "estruturas de pensamento, concepções e práticas que não mais respondem (se é que em algum momento responderam) às verdadeiras necessidades doa aprendizes globais de inglês." (SIQUEIRA, 2011a, p. 110)

\section{A LÍNGUA INGLESA NA SALA DE UALA SOB UMA ÓTICA INTERCULTURAL}

A confluência entre língua e cultura na aula de língua inglesa quando direcionada por uma ótica crítica viabiliza o fomento de uma educação intercultural que transcende a mera descoberta do outro ou o (re)conhecimento daquilo que não se assemelha aos seus hábitos e suas vivências.

Para dar conta da realidade cada vez mais plural da língua inglesa, o professor precisa orientar-se por "uma abordagem de base intercultural, fundada em atitudes democráticas e de acolhimento às diferenças, assim como cercar-se de uma firme crença em práticas dialógicas que venham explorar e valorizar a diversidade inerente a toda e qualquer sala de aula. (SIQUEIRA \& SOUZA, 2014, p. 41)

Certamente, tais propostas apresentam-se ainda nos dias de hoje como grandes desafios para o professor que objetiva ser um mediador intercultural, visto que toda estrutura voltada ao ensino de inglês com base em modelos hegemônicos tem alicerces fortes na educação brasileira decorrentes dos materiais didáticos e de muitos professores que ainda se orientam por crenças pedagógicas que valorizam exacerbadamente tais modelos. Agindo assim, esses docentes não dão espaço e oportunidade em suas aulas para o desenvolvimento de atividades que também apresentem outras variedades da língua inglesa, tanto no aspecto linguístico quanto cultural.

$\mathrm{Na}$ verdade, a despeito dos desafios, ensinar sob uma perspectiva de ILF não é uma tarefa complexa quando temos como proposta principal apresentar aos alunos a diversidade e a heterogeneidade da língua inglesa, fazendo com que eles reflitam se há realmente relevância na busca por modelos de uso da língua com base no falante "nativo padrão". 


\section{O PROFESSOR COMO MEDIADOR INTERCULTURAL}

De acordo com Kalva \& Ferreira (2011, p. 169), a concepção de inglês padrão no meio educacional, tanto de ensino de línguas quanto de formação de professores, ainda é muito enfatizada. Sendo assim, a formação do professor precisa ser um aspecto fundamental para que práticas voltadas ao ensino monolítico da língua inglesa sejam repensadas e deem lugar à diversidade e multiplicidade da língua inglesa. Corroborando essa questão, Dewey (2014 apud GIMENEZ, EL KADRI, ET AL., 2015, p. 611), aponta para a necessidade de uma maior compreensão e de atitudes mais proativas no tocante ao ILF por parte dos professores não-nativos para que eles se tornem profissionais conscientes deste construto, haja vista que é a única maneira de se desviar a atenção do fardo pesado do idealístico e irreal falante nativo.

Ancorado nessa visão crítica, o professor precisa conceber ILF como "uma proposta que reitera a necessidade de se interrogar explicitamente o caráter normativo das práticas de linguagem valorizadas no contexto escolar." (CALVO, EL KADRI \& GIMENEZ, 2014, p. 301). Dessa forma, o papel do professor de inglês é o de preparar os alunos para serem cidadãos aptos a lidar com todas as formas de falar inglês (RAJAGOPALAN, 2009b, p. 45). Ou seja, dentre tantos desafios, o professor, sob a ótica da interculturalidade, precisa incentivar os alunos a reconhecerem a língua em suas especificidades formais, culturais e contextuais. (SIQUEIRA \& BARROS, 2013, p. 21)

Cabe também lembrar que professores não são somente profissionais, eles são também seres humanos que, por muitas vezes, carregam, mesmo que inconscientemente, ideias estereotipadas e preconceituosas acerca de outras culturas. (BYRAM, GRIBKOVA ET AL., 2002, p. 35). Portanto, o professor, para ser um mediador intercultural precisa também ser crítico de si mesmo, analisando suas visões e posturas a fim de que não acabe reproduzindo em suas aulas práticas que mais refletem uma visão equivocada de língua/cultura.

Nesse sentido, a figura do professor-mediador intercultural poderia ser descrita como a de um professor sensível, não somente ao reconhecimento da diversidade cultural, mas também ao seu próprio modo interagir e de pensar outras culturas.

\section{O ALUNO COMO CIDADÃO INTERCULTURAL}

Ser um cidadão intercultural implica desenvolver certas competências que viabilizam um olhar sensível para as questões políticas, sociais e educacionais que envolvem o ensino de língua/cultura. Segundo Byram (2008, p. 163-164), uma 
dessas competências é a consciência cultural crítica, que pode ser definida como a habilidade de avaliar crítica e criteriosamente perspectivas, práticas e produtos de sua e de outras culturas. Os outros elementos que auxiliam o desenvolvimento de um cidadão intercultural seriam:

- As atitudes que geram curiosidade e prontidão para aceitação de outras culturas e de sua própria;

- O conhecimento de grupos sociais com suas práticas e produtos e de processos de interação individuais e na sociedade;

- A habilidade de interpretação de outra cultura aliada à habilidade de explicar e de relacionar essa outra cultura a sua própria;

- As habilidades de aquisição de novo conhecimento de outras culturas e suas práticas e o saber e lidar com esse conhecimento nos momentos reais de comunicação e interação.

Cabe ressaltar que a responsabilidade de se tornar um cidadão intercultural é de todos que fazem parte do processo educativo. Tanto alunos quanto professores precisam desenvolver essas competências. Todavia, diante dos elementos que compõem a competência intercultural, observamos que, a despeito do avanço da globalização, bem como da quebra de fronteiras que permitem um maior acesso a novas culturas, o cenário educacional no Brasil ainda tem seus alicerces bastante fundamentados no ensino de uma língua inglesa supostamente homogênea, monolítica e padrão. Como bem pontua Siqueira (2011a, p. 101), a pedagogia mundial de línguas estrangeiras, principalmente do inglês, que hoje movimenta uma indústria editorial bilionária esteve sempre relacionada a parâmetros ditados pelo círculo central com a aquiescência e silêncio de muitos profissionais da área.

No entanto, de acordo com o autor supracitado, estudos também mostram que esse cenário vem sofrendo modificações e muitos profissionais têm adotado uma perspectiva intercultural de ensino. Ao invés de reforçarem uma postura que poderíamos alcunhar de alienada, esses professores adotaram uma visão crítica com vistas a levarem seus alunos a refletir sobre o impacto da hegemonia das culturas dominantes de língua inglesa no mundo, fazendo com que a cultura no ensino ILF torne-se um tema de grande relevância político-pedagógica.

\section{A SALA DE AULA COMO ESPAÇO INTERCULTURAL}

O desenvolvimento do ensino de língua inglesa a partir de um viés intercultural demanda um professor mediador que traga para sala de aula propostas de ensino que 
permitam ao aluno experimentar situações de comunicação com a língua alvo que vão além do contato com esquemas disponíveis no sistema linguístico. (SIQUEIRA \& ANJOS, 2012 p. 138)

Apesar do contato cotidiano por meio da música, filmes, séries, etc. que a maioria dos alunos já estabelece com as diversas variedades da língua inglesa, o enfoque à pluralidade do idioma no contexto escolar ainda precisa ser mais fortalecido. A impressão é a de que existem mundos dicotômicos no que tange ao contato dos alunos com o inglês na escola, pois, nela, os alunos geralmente se relacionam com um idioma caracterizado por sua homogeneidade, engessamento e padronização, enquanto nas práticas cotidianas, eles interagem com sua pluralidade.

Portanto, como um espaço de aprendizagem e interação de conhecimentos, o papel da escola precisa ser mais enfático na implementação de práticas que fomentem a pluralidade da língua inglesa, promovendo, assim, uma maior integração entre o contexto escolar e as práticas diárias dos alunos, como a participação em redes sociais e/ou fóruns virtuais nos quais os mais variados falantes utilizam a língua inglesa de caráter heterogêneo para compartilhar ideias.

\section{METODOLOGIA DE PESQUISA}

Diante do exposto, analisamos no presente estudo algumas respostas de alunos do $2^{\circ}$ ano do Ensino Médio Regular noturno de uma escola estadual sobre a heterogeneidade da língua inglesa em uma atividade de compreensão oral, objetivando também analisar suas impressões, conceitos e preconceitos acerca dos modelos de fala apresentados na atividade, a saber, um modelo de origem comumente legitimada e hegemônica e outro geralmente concebido como nãopadrão.

Deve-se destacar que tal objetivo alinha-se a uma ótica intercultural de ensino de ILF na medida em que os alunos são levados a refletir sobre suas opiniões, bem como a problematizar as crenças que subjazem seus pensamentos e posturas.

Neste trabalho de cunho qualitativo, os participantes são a professora regente de língua inglesa, que também é autora da presente pesquisa, e os alunos de duas turmas de $2^{\circ}$ ano do Ensino Médio Regular noturno do mencionado Colégio Estadual Pandiá Calógeras.

$\mathrm{O}$ presente estudo alinha-se ao paradigma qualitativo devido ao fato de a pesquisadora poder relatar algumas experiências situacionais, bem como selecionar as atividades e os contextos que oferecem possibilidade de compreender os pontos mais interessantes da pesquisa. (STAKE, 2011, p. 68) 
Por fim, os procedimentos para geração de dados foram realizados por meio das respostas dos alunos apresentadas durante uma atividade de compreensão oral proposta. Cabe ressaltar que essa atividade não foi desenvolvida no início do ano - fato que viabilizaria a implementação de outras atividades de viés intercultural e o aprofundamento da análise - porque esses alunos passaram a ter aulas de inglês a partir do segundo semestre de 2017, após a reordenamento de algumas turmas da escola.

\section{ANÁLISE E DISCUSSÃO DE DADOS}

A atividade de compreensão oral (v. Apêndice 1) a ser discutida teve como base uma entrevista entre um norte-americano e um indiano. A partir dessa entrevista, foi elaborado um questionário que objetivou investigar a opinião dos alunos sobre duas variedades da língua inglesa apresentadas no áudio. É importante salientar que, a princípio, os alunos somente ouviram o áudio da entrevista sem a identificação da imagem e da nacionalidade dos interlocutores. Ou seja, na primeira parte da atividade, eles ouviram o áudio sem a apresentação desses elementos para evitar que criassem antecipadamente algum juízo de valor em relação aos sotaques. No entanto, foi possível observar que a crença de que o inglês de origem hegemônica é o mais "padrão" e "original" está arraigada fortemente nesses alunos, pois grande parte deles apontou a fala do personagem Todd (o nativo norte-americano) como a mais fluente, a despeito de sua nacionalidade não ter sido revelada nessa etapa da atividade.

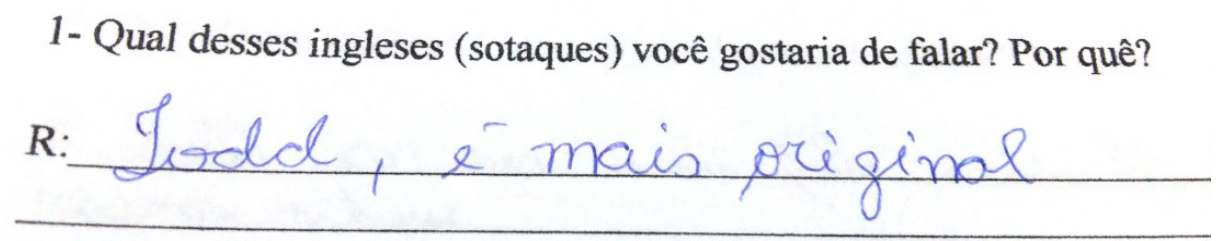

Figura 1 
1- Qual desses ingleses (sotaques) você gostaria de falar? Por quê?

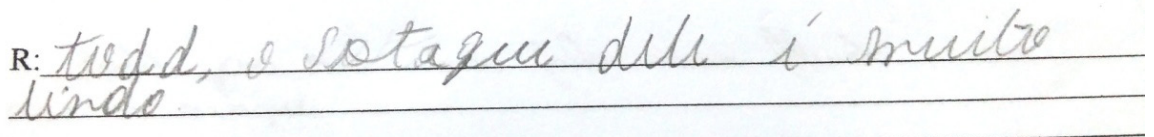

Figura 2

1- Qual desses ingleses (sotaques) você gostaria de falar? Por quê?

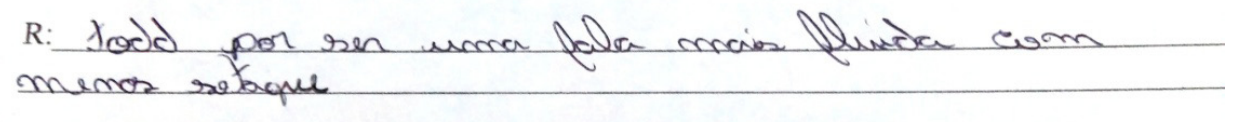

Figura 3

Já a fala de Nanju, o indiano, além de ser preterida por muitos, não foi classificada como fluente. $\mathrm{Na}$ verdade, dentre os 27 alunos participantes, apenas 5 preferiram o sotaque de Nanju por terem a impressão de ser uma variedade mais fácil de ser aprendida e entendida.

1- Qual desses ingleses (sotaques) você gostaria de falar? Por quê?

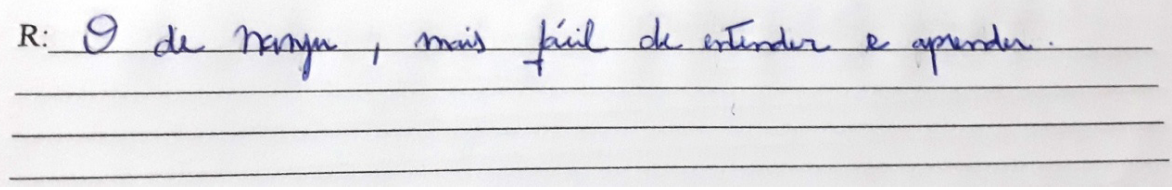

Figura 4

Em linhas gerais, a predileção pelo sotaque norte-americano superou muito a pelo sotaque indiano. Vale lembrar que os alunos fizeram essa escolha com base nas primeiras impressões sobre a nacionalidade dos personagens; contudo, após a identificação delas, essa predileção continuou sendo confirmada: 


\section{Respostas do alunos de duas turmas de $2^{\circ}$ ano sobre a ativida de de compreensão auditiva:}

\section{7 respondentes}

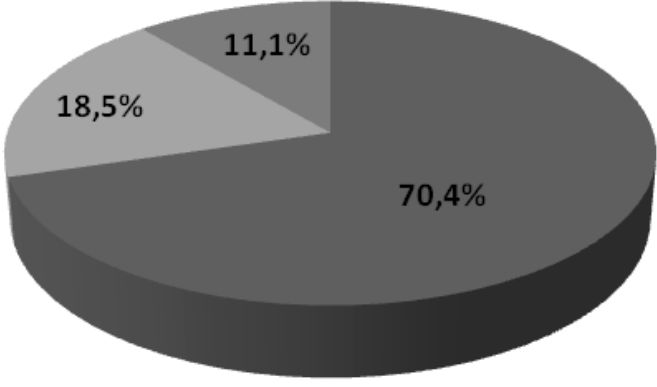

- Preferem o sotaque de Todd

Preferem o sotaque de Nanju

- Não souberam opinar

Gráfico 1

Essa análise inicial confirma a necessidade de uma maior ênfase a ser dada ao ensino intercultural de ILF e, por conseguinte, ao desenvolvimento de atividades que viabilizem o contato dos alunos com outras variedades da língua inglesa no contexto escolar. Ou seja, é preciso promover uma conscientização sobre a importância de todas as variedades, pois, de forma inconsciente, os educandos repetem e reproduzem uma visão limitada de língua, pois, muitas vezes, nunca foram apresentados a outra perspectiva de aprendizagem no contexto escolar. Em outras palavras, tanto pela influência dos materiais didáticos quanto dos professores, muitos estudantes têm uma trajetória educacional marcada pelo foco no aprendizado de uma língua inglesa hegemônica e homogênea.

Quanto à sequência do exercício, após a primeira etapa em que os alunos somente ouviram e responderam à primeira pergunta, eles ouviram novamente a entrevista, seguindo sua transcrição e visualizando as fotos de seus participantes. Nessa etapa, os educandos puderam identificar as nacionalidades dos personagens e discutir as crenças subjacentes às suas opiniões iniciais sobre os sotaques. Alguns 
deles até pontuaram que desconheciam o fato de a língua inglesa também ser falada na Índia como língua oficial, dentre muitas outras línguas locais.

É interessante observar que muitos deles justificaram sua predileção pela fala do norte-americano por estarem mais habituados a ouvirem esse modelo de inglês nas músicas, filmes e mídias em geral. Entretanto, é importante também que esses alunos tomem conhecimento de que o modelo nativizado, também reproduzido pelos meios de comunicação, não reflete o uso da língua inglesa espalhada no mundo, pois segundo Rajagopalan (2005, p.151 apud SIQUEIRA, 2011b), estimativas apontam que dois terços dos usuários do inglês são aqueles que são identificados como não nativos.

Objetivando o fomento de uma reflexão crítica sobre a presença da língua inglesa no mundo, ao final da atividade, foi proposto que os alunos debatessem as ideias e opiniões apresentadas, promovendo a problematização do tema. Dessa forma, essa proposta final objetivou combater o preconceito linguístico, assim como dar início à formação de uma consciência político-linguística desses alunos perante o mundo globalizado.

Por fim, com base nos resultados, observamos que a competência intercultural realmente não é um elemento intrínseco às relações humanas. É importante que a escola esteja atenta a essas questões e busque formas, juntamente com os professores, de trazer para a aula de inglês o aspecto plural e multifacetado desse idioma, auxiliando, assim, na formação de cidadãos que consigam aprender a língua sem estar subjugados e limitados a modelos.

\section{CONSIDERAÇÕES FINAIS}

O fomento do ensino intercultural de inglês sob um viés crítico demanda comprometimento de todos envolvidos na esfera educacional, haja vista que todo o processo precisa ser co-construído por meio da parceria entre escola, professor e aluno.

Ainda em relação ao contexto educacional, Gorski (2008, p 519) assinala que na esfera intercultural existem duas portas: uma aponta para a homogeneidade da língua, fortalecendo a distribuição desigual de poder e as formas de controle, enquanto a outra, mais complexa e que exige maior esforço para mover, nos conduz a um lugar de vulnerabilidade pessoal e institucional, que, por outro lado, combate as realidades sociopolíticas.

De certa forma, as asserções de Gorski desvelam os motivos que conduzem tantos alunos e professores a resistirem em vislumbrar a língua inglesa por uma 
ótica plural. Em analogia às portas mencionadas anteriormente, percebemos que a primeira, além de apresentar uma perspectiva conformista em relação à suposta homogeneização e padronização da língua, também mantém culturalmente insensíveis aqueles que decidem adentrá-la. Já as dificuldades para se abrir a segunda porta, apesar de serem um fator complicador, não se apresentam como obstáculo para aqueles professores que objetivam reproduzir, no contexto escolar, modelos que refletem a língua inglesa no mundo atual.

Portanto, para que maiores passos em direção à implementação de uma educação linguística intercultural sejam dados, professores, alunos e escola precisam trabalhar em conjunto, tornando, assim, a abertura da segunda porta um ato mais leve e corriqueiro.

\section{$\overline{\text { REFERÊNCIAS }}$}

BYRAM, M. (2008). From Foreign Language Education to education for Intercultural Citizenship: essays and reflections. Clevedon, Bufalo, Toronto: Multilingual Matters.

BYRAM, M.; GRIBKOVA, B. et al. (2002). Developing the intercultural dimension in language teaching: a practical introduction for teachers. Language policy division: Council of Europe.

CALVO, L. C. S.; EL KADRI, M. S.; GIMENEZ, T. (2014). Inglês como língua franca na sala de aula: sugestões didáticas. In: EL KADRI, M. S.; et al. (Orgs.). Tendências contemporâneas para o ensino de língua inglesa: propostas didáticas para a educação básica. Campinas, S.P: Pontes Editores, p. 299-316.

CRYSTAL, D. (2003). English as a global language. UK: Cambridge University Press.

FARACO, C. A. (2007). Por uma pedagogia da variação linguística. In: CORREIA, Djane Antonucci. (Org.) A relevância social da linguística: linguagem, teoria e ensino. São Paulo: Parábola Editorial, p. 21 - 50.

FERNANDES, E. C. S.; EIRÓ, J. G (2013). Experiências interculturais e aquisição de língua estrangeira e/ou segunda língua. In: BRAWERMAN-ALBANI, A.; MEDEIROS, V. S. (Orgs.). Diversidade cultural e ensino de língua estrangeira. Campinas, SP: Pontes Editores, p. 97-110.

GIMENEZ, T.; CALVO, L. C. S.; EL KADRI, M. S. (2011). (Orgs.) Inglês como língua franca: ensino-aprendizagem e formação de professores. Campinas, SP: Pontes Editores. 
GIMENEZ, T.; CALVO, L. C. S.; EL KADRI, M. S.; EL KADRI, M. S. et al. (2015). Inglês como lingua franca: desenvolvimentos recentes. Disponível em: $<\underline{\text { http://www.scielo.br/pdf/ }}$ rbla/v15n3/1984-6398-rbla-15-03-00593.pdf $>$ Acesso em: 29 de janeiro de 2019.

GORSKI, P. C. (2008). Good intentions are not enough: a decolonizing intercultural education. Intercultural education, v. 19, n. 6, p. 515-525.

JENKINS, J.; COGO, A. (2011). et al. Review of developments in research into English as a lingua franca. Disponível em: $<$ https://www.cambridge.org/core/journals/languageteaching/article/review-of-developments-in-research-into-english-as-a-lingua-franc a/47A99C70A696371F7F9F06351D0963F1> Acesso em: 27 de janeiro de 2019.

KACHRU, B B. (1985). Standards, codification and sociolinguistic realism: the English language in the outer circle. In: QUIRK, Randolph; WIDDOWSON, H. G. (Orgs.). English in the World: Teaching and Learning the Language and Literatures. Cambridge: Cambridge University Press, p. 11-33.

KALVA, J. M.; FERREIRA, A. J. (2011). Inglês como língua franca e a concepção de identidade nacional por parte do professor de inglês: uma questão de formação. Forum Linguist., v.8, n. 2, p. 165-176.

KRAMSCH, C. (2013). Culture in foreign language teaching. Disponível em: $<\underline{\text { http://ijltr.urmia. }}$ ac.ir/article 20453 707cf14e180ff24ca190f3f34a236e3e.pdf $>$ Acesso em: 29 de janeiro de 2019.

MILROY, J. (2011). Ideologias linguísticas e as conseqüências da padronização. In.: LAGARES, X. C.; BAGNO, M. (Orgs.). Políticas da norma e conflitos linguísticos. São Paulo: Parábola Editorial, p. 49- 87.

PENNYCOOK, A. (2010). Rethinking origins and localization in global Englishes. In: SAXENA, M.; OMONIYI, T. (Orgs.) Contending with globalization in World Englishes. UK: Multilingual Matters, p. 196-233.

RAJAGOPALAN, K. (2009a). "World English" and the Latin Analogy: where we get it wrong. English Today, vol, 24, n² 2, junho, p. 46-51.

RAJAGOPALAN, K. (2009b). O inglês como língua internacional na prática docente. In: LIMA, Diógenes Cândido de. (Org.). Ensino aprendizagem de língua inglesa: conversas com especialistas. São Paulo: Parábola Editorial, p. 39-46. 
RAJAGOPALAN, K. (2014). O professor de línguas e a suma importância do seu entrosamento na política linguística do seu país. In: CORREA, Djane Antonucci (Org.). Política linguística e ensino de língua. Campinas, SP: Pontes Editores, p. 73-82

ROCHA, C. H. (2009). A língua inglesa no ensino fundamental I público: diálogos com Bakhtin por uma formação plurilíngue. Trab. linguist. apl., v.48, n.2, p. 247-274.

SIQUEIRA, D. S. P. (2011a). Inglês como língua franca: o desafio de ensinar um idioma desterritorializado. In: GIMENEZ, Telma; CALVO, Luciana C. Simões; EL KADRI, Michele Salles. (Orgs.) Inglês como lingua franca: ensino-aprendizagem e formação de professores. Campinas, SP: Pontes Editores, p. 87-115.

SIQUEIRA, D. S. P. (2011b). World Englishes, World English: inglês como língua internacional, inglês como língua franca. In: LAGARES, Xoán Carlos; BAGNO, Marcos (Orgs.). Políticas da norma e conflitos linguísticos. São Paulo: Parábola Editorial, p. 333-354.

SIQUEIRA, D. S. P. (2012). Se o inglês está no mundo, onde está o mundo nos materiais didáticos de inglês? In: SCHEYERL, Denise; . (Orgs.) Materiais didáticos para o ensino de línguas na contemporaneidade: contestações e proposições. Bahia: Editora da UFBA, p. 311-353.

SIQUEIRA, D. S. P.; ANJOS, F. A. dos. (2012). Ensino de inglês como língua franca na escola pública: por uma crença no seu (bom) funcionamento. Muitas Vozes, v.1, n.1, p. $127-149$.

SIQUEIRA, D. S. P.; BARROS, K. S. (2013). Por um ensino de inglês como língua franca. Estudos Linguísticos e Literários, n. 48, p. 5-39.

SIQUEIRA, D. S. P.; SOUZA, J. S. (2014). Inglês como língua franca e a esquizofrenia do professor. Estudos Linguísticos e Literários, n. 50, p. 31-64.

SOUZA, A. G. F.; BARCARO, C. F. et al. (2011). As representações de alunas-professoras de um curso de letras sobre o estatuto do inglês como língua franca. In: GIMENEZ, T.; CALVO, L. C. S.; EL KADRI, Michele Salles. (Orgs.) Inglês como língua franca: ensino-aprendizagem e formação de professores. Campinas, SP: Pontes Editores, p. 193-220.

STAKE, R. E. (2011). Pesquisa Qualitativa: estudando como as coisas funcionam. Porto Alegre: Penso. 


\section{APÊNDICE 1. ATIVIDADE DE COMPREENSÃO ORAL DESENVOLVIDA NAS TURMAS DE $2^{\circ}$ ANO DO ENSINO MÉDIO}

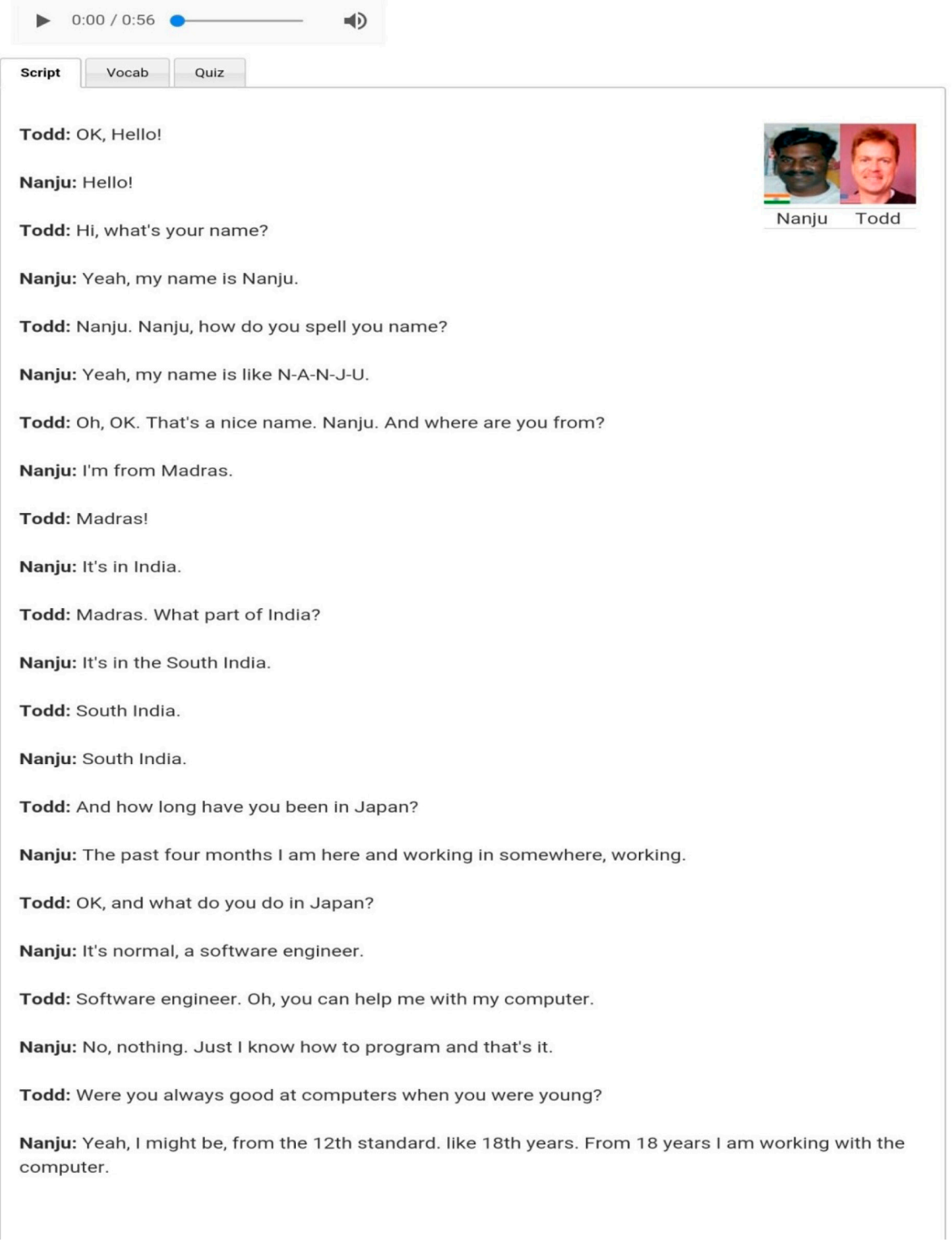

Fonte: http://www.elllo.org/english/0151/170-Naju-Introduction.htm 
C.E Pandiá Calógeras

São Gonçalo, de de 20

Professora: Flávia Matias Silva

Nome: Turma:

Disciplina: Inglês

I- Responda às perguntas sobre o diálogo:

1- Qual desses ingleses (sotaques) você gostaria de falar? Por quê? $\mathrm{R}:$

2- Você consegue identificar as nacionalidades das pessoas que conversam no diálogo? Se sim, quais seriam?

$\mathrm{R}:$

3- O que te fez (ou não te fez) identificar cada nacionalidade?

$\mathrm{R}:$

4- Com qual variedade da língua inglesa você tem mais contato, a de Todd ou a de Nanju? $\mathrm{R}:$

5- Quais seriam os principais meios desse contato? Músicas, series, TV, Internet...? $\mathrm{R}:$

Recebido: $7 / 12 / 2018$

Aceito: 15/02/2019

Publicado: 29/03/2019 